\title{
O DIGITAL INFLUENCER E AS IMPROBABILIDADES COMUNICATIVAS NAS REDES SOCIAIS
}

\author{
Lidiane Duca Silva* \\ Germano André Doerdelein Schwartz**
}

SUMÁRIO: Introdução; 1.1 A comunicação improvável por meio das redes sociais; 2 A rede social sendo utilizada como transmissor da vida cotidiana; 3 O digital influencer e os meios de comunicação digital; 4 Considerações finais; Referências.

RESUMO: A análise se dá sobre a comunicação nas redes sociais como um sistema complexo que, por meio das improbabilidades comunicativas que se transformam em probabilidades, alcança sentido e compreensão perante os receptores. O presente trabalho, a partir da análise da rede social e utilizando como metodologia a revisão de literatura, alcança o ponto de vista do emissor da comunicação que a utiliza como forma de transmissão de sua vida cotidiana, em busca do reconhecimento do ser social virtual. Sob esse teor, muitos dos emissores da mensagem buscariam a criação de um perfil virtual ideal que engloba o ser, o ter e o parecer, transformando o que antes era reconhecimento de identidade pessoal em uma eterna busca por destaque social, utilizando a imagem como elemento primordial para alcançar seguidores, relações de consumo e destaque de opiniões pessoais, políticas e religiosas. $\mathrm{O}$ fenômeno que engloba a rede social a transforma em um aparato mercadológico que por finalidade a busca incessante por reconhecimento e utiliza a comunicação como forma de dominação das massas na Sociedade do Espetáculo.

PALAVRAS-CHAVE: Digital Influencer; Improbabilidade da comunicação; Rede social; Sociedade do Espetáculo.

\section{DIGITAL INFLUENCER AND COMMUNICATION IMPROBABILITIES IN SOCIAL NET WORKS}

ABSTRACT: Communication in social networks as a complex system analyzed through communication improbabilities that transform themselves in probabilities is understood by receivers. Through the analysis of social networks and a literature review, current analysis reaches the point of view of the emitter that uses communication as a form of transmission of daily life for the acknowledgement of the

\footnotetext{
* Mestre em Direito da Sociedade da Informação pelo Centro Universitário Faculdades Metropolitanas Unidas (FMU). Docente e Coordenadora Adjunta do Curso de Direito do Centro Universitário Faculdades Metropolitanas Unidas (FMU). Docente do Complexo Andreucci de Ensino Jurídico, Brasil.

E-mail: lidianeduca@gmail.com

${ }^{* *}$ Faculdades Metropolitanas Unidas (FMU), Brasil.
} 
virtual social being. Several message emitters would seek the establishment of an ideal virtual profile that comprises being, having and seeming, transforming what was formerly acknowledgement of personal identity into an eternal search for social enhancement. The image is used as a primordial element to reach followers, consumption relationships and enhancements in personal, political and religious opinions. The phenomenon that comprises the social network transforms it into a marketological apparatus with an everlasting process for acknowledgement. It uses communication as a form of mass dominance of the Society of the Spectacle.

KEY WORDS: Digital Influencer; Improbability of communication; social network; Society of the Spectacle.

\section{EL DIGITAL INFLUENCER Y LAS IMPROBABILIDADES COMUNICATIVAS EN LAS REDES SOCIALES}

RESUMEN: El análisis se da sobre la comunicación en las redes sociales como un sistema complejo que, por intermedio de las improbabilidades comunicativas que se transforman en probabilidades, alcanza sentido y comprensión delante de los receptores. El presente estudio, a partir del análisis de la red social y utilizándose como metodología la revisión de literatura, alcanza el punto de vista del emisor de la comunicación que la utiliza como forma de transmisión de su vida cotidiana, en búsqueda del reconocimiento del ser social virtual. Bajo ese contenido, muchos de los emisores del mensaje buscarían la creación de un perfil virtual ideal que abarca el ser, el tener y el parecer, transformando lo que antes era reconocimiento de identidad personal en una eterna búsqueda por destaque social, utilizando la imagen como elemento primordial para alcanzar seguidores, relaciones de consumo y destaque de opiniones personales, políticas y religiosas. El fenómeno que abarca la red social la transforma en un aparato mercadológico que por finalidad la búsqueda incesante por reconocimiento y utiliza la comunicación como forma de dominación de las masas en la Sociedad del Espectáculo.

PALABRAS CLAVE: Digital Influencer; Improbabilidad de la comunicación; Red social; Sociedad del Espectáculo. 


\section{INTRODUÇÃO}

O tema deste trabalho inscreve-se nos estudos da teoria da improbabilidade da comunicação de Niklas Luhman, em que a comunicação é o ponto focal das relações humanas. Nela, o entendimento e a compreensão da mensagem transmitida baseiam-se em formas improváveis, como a memória, o contexto, a extensão temporal e espacial e o alcance do objetivo da comunicação.

A relevância deste estudo se dá pela abrangência da compreensão da comunicação em ambiente virtual, propriamente dita em uma rede social. Nesse processo, muitas vezes, as pessoas que estão exercendo a comunicação não se conhecem pessoalmente ou nem mesmo compartilham ideologias semelhantes, porém por meio das improbabilidades estão em um mesmo ambiente virtual e compreendem a mensagem emitida.

O presente esforço se justifica tanto do ponto de vista sociológico como acadêmico, além, obviamente, do pessoal. Do ponto de vista social, o estudo busca responder às questões surgidas da própria comunicação, e de sua assertiva virtual, tendo em vista que milhares de fatos virtuais comunicativos ocorrem a cada segundo e de forma globalizada.

Do ponto de vista acadêmico, o estudo se justifica haja vista as teorias comunicativas apresentadas por Luhmann, o amparo legal ao meio virtual e a proteção da liberdade pessoal de expressão, que é reconhecida pela Constituição Federal. Ainda em mesmo sentido, faz-se necessário o estudo das novas formas identitárias surgidas por meio das redes sociais, como é o caso do digital influencer que utiliza a sua rede social como uma vitrina de ideias, produtos e serviços, receitas e pensamentos, com a utilização de vídeos, imagens e textos como formas comunicativas. Assim, a produção científica é pouco abundante e, por isso, é fácil entender a importância acadêmica do tema e a justificativa para o presente estudo.

Do ponto de vista pessoal, os autores, por diferentes caminhos de atuação profissional e acadêmica, de um modo ou de outro, há muito tempo, interessam-se pelas teorias comunicativas de Niklas Luhmann e os reflexos dessas teorias na sociedade da informação, de maneira interdisciplinar nos meios de comunicação em massa, sejam eles meios de difusão, ou de comunicação simbolicamente generalizados.

A metodologia empregada para o presente estudo, fundamentalmente, consiste na revisão bibliográfica crítica, seja na bibliografia relativa aos estudos doutri- 
nários jurídicos, seja naquela relativa aos estudos das ciências sociais de um modo amplo que discutem a possibilidade de se garantir uma comunicação eficaz perante as redes sociais e o estudo das influências exercidas pela comunicação em massa.

A revisão bibliográfica também aborda os estudos relativos à comunicação ante o uso de meios de comunicação em massa, redes sociais, e as teorias das improbabilidades comunicativas como forma de acesso à comunicação virtual e da influência, que se aproveita o indivíduo para alcançar notoriedade perante seus seguidores.

$\mathrm{O}$ artigo compreende, após essa introdução, as seguintes seções: 1.1 A comunicação improvável por meio das redes sociais; 2 A rede social utilizada como transmissor da vida cotidiana. $3 \mathrm{O}$ digital influencer e os meios de comunicação digital. 4 Considerações finais.

\subsection{A COMUNICAÇÃO IMPROVÁVEL POR MEIO DAS REDES SOCIAIS}

A comunicação é fundamental ao ser humano em suas relações sociais. Uma das características do grupo social consiste na identificação de pensamentos e anseios semelhantes aos dos indivíduos que compõem seu grupo social. Essa identificação se dará por meio da expressão de um pensamento individual que será consonante com os anseios dos demais indivíduos para a formação da relação social integrada.

Sendo a comunicação intrínseca ao convívio social, não surge apenas de uma expectativa motora ou pela busca de melhores condições, mas aparece de forma improvável, conforme a teoria de Luhmann, em que, para estabelecer uma comunicação eficaz, há fatores internos e externos que corroboram com a formação comunicativa. Para Luhmann

[...] é improvável que alguém compreenda o que o outro quer dizer, tendo em conta o isolamento e a individualização de sua consciência. O sentido só se pode entender em função do contexto, e para cada um o contexto é, basicamente, o que sua memória faculta ${ }^{03}$.

De acordo com a assertiva acima citada, a compreensão da comunicação se dá pela contextualização trazida pela memória do receptor. A comunicação eficaz traz consigo fatores essenciais à emissão de signos, que alcançarão significantes

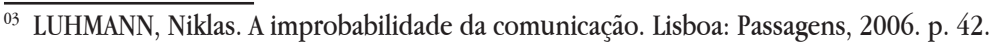


diversos ao serem interpretados pelo indivíduo receptor de acordo com a sua memória, consciência e extensão espacial e temporal. Dessa forma, a comunicação nem sempre alcança o resultado almejado, qual seja: o entendimento da expressão.

Com a sociedade da informação e a utilização das redes sociais como forma de expressão de fatos, opiniões, imagens e a abrangência social que o meio informático possui, os problemas de comunicação se tornam a cada dia mais evidentes na rede. Isso decorre do fato de que a interpretação de cada indivíduo para fatos diversos é própria do convívio em seu meio sistêmico.

Além da interpretação diversa de cada fato, outra problemática trazida por Luhmann na teoria das improbabilidades comunicativas é a "extensão espacial e temporal" ${ }^{\prime 4}$. Se a expressão de uma mesma informação for analisada em três grupos sociais diversos, a interpretação encontrará divergências em cada um deles. Em mesmo sentido, a informação será interpretada de forma diversa e, conforme a extensão espacial e temporal de cada grupo, as compreensões também divergirão.

A comunicação em rede é essencial para a sociedade da informação. Para os indivíduos, a problemática da comunicação não será impeditiva à expressão de sua opinião em uma rede social ou à divulgação de sua imagem, pois eles estarão satisfeitos no momento em que garantirem que a mensagem enviada alcançou a maior quantidade de destinatários, bem como o objetivo proposto, além da maior quantidade de curtidas, comentários e compartilhamentos.

A terceira improbabilidade trazida por Luhmann é o embasamento principal do presente trabalho, pois define-se nela o comportamento do indivíduo em sua rede social e a formação de sua identidade virtual, com o alcance do objetivo de sua comunicação.

A terceira improbabilidade é a de obter o resultado desejado. Nem sequer o facto de que uma comunicação tenha sido entendida garante que tenha sido também aceita. Por resultado desejado, entendo o facto de que o receptor adopte o conteúdo selectivo da comunicação (a informação) como premissa do seu próprio comportamento incorporando à novas selecções e elevando assim o grau de selectividade. A aceitação como premissa do próprio comportamento pode significar actuar em virtude das directrizes correspondentes, bem como experimentar, pensar e assimilar novos conhecimentos, supondo que uma determinada informação seja correcta. ${ }^{05}$

${ }^{05}$ LUHMANN, Niklas. A improbabilidade da comunicação. Lisboa: Passagens, 2006. p. 43. 
$\mathrm{Na}$ rede social, a comunicação nem sempre se dará por meio de signos linguísticos nas mensagens escritas, já que o desdobramento comunicativo vai além da escrita. Em redes sociais, cuja exposição fotográfica é o foco, a comunicação se dará única e exclusivamente por meio da propagação de uma imagem.

Ao utilizar essa rede social, o indivíduo, que busca a comunicação por meio daquele signo, não demonstra o contexto, mas apenas o instante em que o fato ocorreu, restringindo a interpretação e a extensão comunicativa àquela imagem. A exposição do indivíduo em rede social abrange muito mais do que a expressão comunicativa escrita ou figurativa, alcançando até a comunicação em vídeos por tempo real e com extensão comunicativa temporal de 24 horas.

[...] a sociedade criou, autoproduziu, comunicações; poder-se-ia dizer, em uma outra perspectiva, linguagens ou modelos, mas prefere-se dizer que surgiram sistemas. Sistemas que ordenam essa complexidade a partir de certo tipo de perspectiva, conforme o tipo de diferenciação funcional evolutivamente consagrado. ${ }^{06}$

A exposição por vídeo, por meio de redes sociais de transmissão ao vivo ou de tempo limitado, traz ao emissor e ao receptor da mensagem uma proximidade virtual. Ao emissor a comunicação cumpre seu objetivo no momento em que há maior alcance de sua mensagem, ou seja, quanto mais pessoas visualizarem o vídeo, maior satisfação terá o receptor.

Por outro lado, a comunicação por meio dessas redes sociais traz ao receptor a possibilidade de participar, em tempo real, dos acontecimentos diários do emissor. Uma das consequências da utilização dessas redes sociais consiste na virtualização das relações sociais, em que é possível ao receptor participar da vida do emissor, sem que haja um contato pessoal.

A ausência desse contato não é impeditiva à comunicação eficaz. A problemática se encontra, porém, no momento em que acontecimentos rotineiros passam a ser considerados espetáculos a serem vistos, transmitidos, comentados e compartilhados.

${ }^{06}$ ROCHA, Leonel Severo; KING, Michael; SCHWARTZ, Germano. A verdade sobre a autopoiese no direito. Porto Alegre: Livraria do Advogado, 2009. p. 19. 


\section{A REDE SOCIAL UTILIZADA COMO TRANSMISSOR DA VIDA COTIDIANA}

Em redes sociais como Snapchat, Periscope e Instragram, os integrantes podem emitir mensagens de vídeo em tempo real ou com armazenamento de vinte e quatro horas, sobre os acontecimentos de sua vida cotidiana e sobre fatos específicos que desejam compartilhar com seus seguidores. Estes, por sua vez, podem compartilhar momentos que lhe interessem, fazer comentários sobre os fatos, aprovar os vídeos por meio de curtidas e até mesmo copiar frações de vídeos.

A rede social, que até meados de 2006, era utilizada para definir relações de amizade, por meio do extinto Orkut, tornou-se um meio de exposição de personalidades, opiniões, produtos e pessoas, dentre tantas outras funcionalidades. Igualmente, pessoas que antes eram desconhecidas utilizaram esse meio para se destacarem em meio à multidão.

A rede social deixou de ser apenas um meio de interação virtual e passou a ser uma grande vitrina. Além de expressar a necessidade de exposição virtual, a quantidade de curtidas em determinada publicação deixou de ser apenas um sinal da quantidade de pessoas que gostaram da comunicação expressa e passou a ser uma forma de julgamento do receptor ao que lhe foi exposto. É o que acontece com as publicações no Facebook nas quais, por meio de Emoticons, é possível ver a expressão de aceitação, reprovação, nervosismo e emoção, em relação ao que fora publicado.

Como Luhmann afirmou, "as improbabilidades não são obstáculos para que a comunicação chegue ao destinatário"07, elas são processos de compreensão da mensagem emitida por meio dos signos. Ao alcançar os objetivos esperados, o emissor da mensagem na rede social irá assimilar e experimentar a aprovação e a reprovação obtidas.

Em uma rede virtual de amizades, o reconhecimento e a aprovação "virtual-social" são os objetivos do indivíduo, que cria a sua identidade virtual, por meio do que julga ser de interesse da maior parte das pessoas que compõem o grupo de seus seguidores. A relação virtual entre o emissor e o receptor da comunicação se torna cada vez mais próxima, tendo em vista que, de acordo com a expressão de aprovação dos receptores, o emissor identifica o que deve postar para "agradar" a seu público.

Nesse sentido, aplicam-se os "fatores de dissuasão" 08 nos quais a busca por

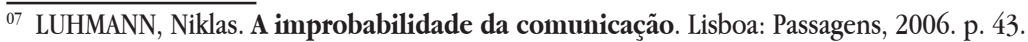

${ }^{08}$ Idem.
} 
objetivos positivos nem sempre é alcançada. Isso porque o receptor poderá exprimir a reprovação em face do que se está comunicando. Dessa forma, a cada postagem, o emissor precisa inovar e, ao mesmo tempo, manter a coerência com suas mensagens anteriores, tornando os seus momentos mais simples em grandes espetáculos a serem julgados pela massa.

$O$ reconhecimento trazido pela exposição na rede social faz com que o indivíduo busque a utopia comunicativa, presenciando a necessidade de abandonar a sua identidade social, e assumindo a identidade virtual em sua vida cotidiana. Isso se dá pelo fato de identificar que, em suas relações presenciais, possui número limitado de pessoas que participam do cotidiano. Já nas redes sociais a rede de pessoas que participam de sua rotina diária é maior, comprovando a teoria de que a relação virtual possui efeitos no cotidiano dos influencers e de seus seguidores.

Quanto mais seguidores e receptores o indivíduo possuir, maior reconhecimento terá perante a sociedade e o mercado, o que o transformará em um digital influencer. A simples exposição de mensagens vinculadas a opiniões e situações do dia a dia influencia os receptores de maneira tal que o reconhecimento de determinado indivíduo não significa apenas a fama, a rede social sendo vista como uma vitrina de opiniões e aceitações, torna-a um mercado, em que a exposição de pessoas influencia não apenas no ser, mas no ter e no poder ter.

A relação utópica criada pelo receptor, em seus sistemas sociais virtuais, não impede a formação das probabilidades comunicativas advindas das improbabilidades. O emissor da mensagem alcança, na maioria dos casos, os objetivos positivos que desejava, ou seja, ele alcança um número relevante de pessoas em seu sistema social virtual. Esses receptores compreendem a mensagem que está sendo emitida e demonstram sua aprovação ou reprovação diante daquele fato.

No momento em que a comunicação é afetada e retirada dos indivíduos materialmente presentes e passa a ser uma relação virtual, seja por um vídeo ao vivo, por uma mensagem temporária, por uma foto, ou por uma mensagem escrita, o alcance espacial e temporal multiplicar-se-ão.

O espacial justifica-se quanto ao alcance global da comunicação e o temporal se refere às mensagens instantâneas ou por prazo determinado. Além disso, a rede social e os aparelhos informáticos ainda apresentam ferramentas que possibilitam ao receptor salvar a mensagem proferida ou reproduzi-la em outros momentos. Assim, o alcance da comunicação torna-se irrestrito aos receptores. 
Já a assimilação, a aceitação e a empatia criadas pelo receptor em relação ao emissor fazem com que o receptor busque pela informação emitida por aquele indivíduo, identificando a página virtual como de sua preferência, tornando-se seguidor do perfil do emissor.

E ainda a identificação entre emissor e receptor é tão intensa que o seguidor buscará por informações do emissor, seja assistindo a seus vídeos, comentando e curtindo suas publicações ou mesmo sentindo-se parte da realidade de outrem. $\mathrm{O}$ receptor passa a acompanhar cada fato ocorrido com seu emissor, sabendo o que ele veste, o que come, quais lugares frequenta, assim como detalhes de sua vida pessoal e profissional.

Sendo as redes sociais entendidas como "meio de difusão"09, é possível identificar os emissores que dela se utilizam como sujeitos que exercem a dominação, ou seja, influenciam os que participam ativamente de sua rede social, isto se dá pelo nome de digital influencer ou influenciador.

Na sociedade da informação, a rede social deixou de ser apenas um sistema social virtual de interações. Passou a ser utilizada pelo mercado como uma vitrina, que expõe produtos por meio da influência comunicativa exercida pelos indivíduos sobre seus seguidores.

\section{O DIGITAL INFLUENCER E A IMPROBABILIDADE COMUNICATIVA NAS RE- DES SOCIAIS}

Vários conceitos podem surgir a partir da identidade influenciadora virtual. Não tendo vínculos com os sistemas de imprensa, na mídia social, o influenciador se sente livre para expressar-se da forma que julgar adequada ou que será aceita por seus seguidores.

Essa influência comunicativa representa a forma de dominação entre o influenciador e seu seguidor, ou seja, poderá influenciar o pensamento crítico desse seguidor sobre determinado assunto, sua forma de vestir, de agir, bem como seu modo de vida. Por exemplo: em uma sociedade em que o consumo constitui uma das formas de destaque individual, a imagem passa a ser associada ao produto e o receptor passa a ser considerado público consumidor. Assim, no momento em que

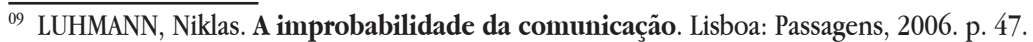


um digital influencer de moda infantil associa as suas publicações a determinada marca, envia ao receptor a mensagem do ter ou poder ter, transformando a relação digital em uma relação de influência consumerista.

No livro a Sociedade do Espetáculo, Debord faz importante crítica à sociedade consumerista, que pode ser reportada ao presente trabalho, na acepção da influência virtual, entre o ser, o ter e o parecer como ações que influenciam diretamente o indivíduo e o fazem desejar produtos, modo de vida e informações.

A primeira fase da dominação da economia sobre a vida social levou, na definição de toda a realização humana, a uma evidente degradação do ser em ter. A fase presente da ocupação total da vida social em busca da acumulação de resultados econômicos conduz a uma busca generalizada do ter e do parecer, de forma que todo o «ter» efetivo perde o seu prestígio imediato e a sua função última. Assim, toda a realidade individual se tornou social e diretamente dependente do poderio social obtido. Somente naquilo que ela não é, lhe é permitido aparecer. $^{10}$

Para Debord a degradação do ser se daria na relação humana pós-moderna, pelo espetáculo social, em que o indivíduo se destacaria em face dos demais pelo que possuísse ou adquirisse na relação de consumo, ou seja, toda a relação do indivíduo dominante estaria firmada no ter ou no parecer. As aparências deveriam ser mantidas com forma de destaque perante os demais, gerando, assim, uma relação de consumo em cadeia. Em outras palavras, a comunicação, por meio do marketing, alcançaria quem pudesse ter e desejaria parecer com indivíduos que se destacassem.

$\mathrm{Na}$ sociedade da informação, o conceito e a estratégia de consumo não se alteraram, porém faz parte atualmente de um ciclo formado pelo influenciador digital. Observe-se que o embasamento do presente trabalho não consiste na relação consumerista, senão na análise da influência digital sobre o indivíduo. Nesse sentido, a formação de uma identidade digital não se baseia na relação de consumo, isto é, não se trata simplesmente da degradação do ser para o ter, mas na comunhão do ser, ter e parecer.

A busca atual não se dá apenas por um dos elementos, o que deixa a relação de consumo, de início, em segundo plano. No momento em que o indivíduo se

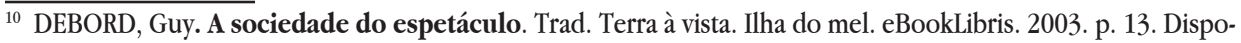
nível em: http://www.cisc.org.br/portal/biblioteca/socespetaculo.pdf Acesso em: 12 jan. 2017. 
insere em uma rede social com um perfil pessoal, a busca que faz reconhecimento do ser, ou seja, a procura do pertencimento e da reafirmação de sua identidade. A rede social reafirma o direito ao pertencimento no momento em que gera ao indivíduo uma rede de alcance de pessoas, que possuem os mesmos intuitos e relações presenciais e virtuais próximas.

$\mathrm{O}$ pertencer a uma rede social e às relações virtuais reafirmam ao indivíduo o ser como sentimento de pertencimento e identidade virtual, que a relação de pertencimento primária foi incapaz de suprir. $\mathrm{O}$ indivíduo está ali para ser visto e reconhecido por pessoas de seu relacionamento pessoal e por desconhecidos que the trarão a sensação de pertencimento a uma comunidade. Isso lhe dá a possibilidade de expressar suas opiniões e permite-lhe que se oponha por instrumentos variados de comunicação (mensagem escrita, foto, vídeo).

Essa dimensão tradicional de pertencimento-comunidade vê-se hoje ampliada a partir do objeto-fim que a define e a constitui como um todo: comunidade imaginada, comunidade virtual, comunidade de apropriação, comunidade interpretativa, comunidades hermenêuticas, sem mencionar inúmeras expressões que as definem tanto por meio de processos mediáticos quanto nas práticas de movimentos sociais, políticos e culturais, além das redes contemporâneas de relacionamento mediadas por novas tecnologias. ${ }^{11}$

Na sociedade da informação, as redes sociais não apenas medeiam, como também intermedeiam as relações humanas, interferindo, por meio de cookies, tal qual o "encontro" de indivíduos que possuem o mesmo interesse. Com interesses semelhantes, o emissor emite mensagens aos seus receptores que, por sua vez, aprovam ou reprovam a comunicação por meio de curtidas e manifestações escritas. Dessa forma, o emissor identifica o padrão de mensagem que melhor agrada o seu público e emite mais comunicações semelhantes, tornando o seu perfil pessoal um espetáculo da vida rotineira a ser mostrado na vitrina da rede social.

O que passa a reger as relações contemporâneas é o imediatismo do tempo presente, uma vez que na fluidez o passado e o futuro perdem suas dimensões, seus sentidos devido a ne-

\footnotetext{
${ }^{11}$ SOUSA, Mauro Wilton de. O pertencimento comum ao mediático. Significação Revistas de Cultura Audiovisual, v. $37, \mathrm{n}^{\circ} 34$, p. 31-52, 2010. Disponível em: < http://www.revistas.usp.br/significacao/article/viewFile/68112/70670 > . Acesso em: 13 jan. 17.
} 
cessidade de aceleração do ritmo da vida que impõe aos indivíduos flexibilidade e simulação frente às exigências sociais. ${ }^{12}$

$\mathrm{O}$ imediatismo, a necessidade de mostrar-se e ser reconhecido perante os demais, faz com que o indivíduo busque na publicação maior retorno e evidência. Surge então a sincronia entre o desejo pelo ser e a necessidade de ter. Considera-se ainda que no aspecto do ser, o reconhecimento se dá de forma velada, enquanto na sociedade de consumo, a busca pelo ter é constante e almejada pelos indivíduos.

Em decorrência, tem-se, de um lado, a relação de consumo atrelada ao perfil pessoal do emissor, que deixa de comunicar apenas a rotina de suas relações pessoais e passa a comunicar o pertencimento por meio das relações consumeristas. De outro o mercado que, a cada dia, busca novas estratégias de marketing para alcançar seus consumidores, reconhece o vínculo entre o ser e o ter virtual para alcançar um maior número de consumidores.

A aliança entre emissores e mercado determina que o emissor deixe de ser alguém que comunica mensagens pessoais ou que compartilha experiências, fazendo-o um influenciador digital. Assim, o indivíduo passa a representar os anseios do mercado e do consumidor. Do primeiro, pela venda; do último por ter produtos que representem a proximidade com seu influenciador.

O seguidor, participando do dia a dia consumerista de seu influenciador, passa a querer ser e ter, ansiando por vestir igual, viajar, frequentar e estar em mesmos locais. Em outras palavras: consumir o que o influenciador "consome". Observe-se que "consome" está na seara do parecer; nem tudo o que o influenciador demonstra perante os meios de comunicação faz parte de sua rotina, ou mesmo, é seu.

Nessa relação do parecer reside a problemática das formas atuais de comunicação, pois produtos são divulgados pelo influenciador como se fossem seus, como se a utilidade de tais produtos fosse essencial ao seguidor, ou ainda eficientes, de modo que cumprissem a imediatidade buscada pelo receptor.

Mais uma vez, a imagem (apropriada pela publicidade) está a serviço da consagração da aparência, criando um vínculo erotizado que por si só não existiria. A imagem é fundamental à medida que se utiliza da visão para criar o vínculo erotizado com o objeto. Desta forma, o consumidor-alvo da propaganda,

\footnotetext{
${ }^{12}$ SANCHES-JUSTO, Joana. A primazia da imagem e a virtualização das relações na cultura das aparências. Revista Espaço Äcadêmico, n. ${ }^{0}$ 153, 2014, p. 4. Disponível em: < http://periodicos.uem.br/ojs/index.php/EspacoAcademico/article/view/22859>. Acesso em: 02 jan. 2017.
} 
erotizado pela aparição da mulher, se torna mais propenso a comprar o relógio como se a mulher, seu real objeto de desejo, viesse "de brinde". A partir do momento em que a imagem se torna central para o mercado, a publicidade vai ao encontro das artes visuais, se associando a artistas na busca de novos materiais e estilos para a criação de marcas e imagens de produtos. $^{13}$

Os influenciadores se tornaram os novos "rostos" dos produtos e serviços. Os mercados os utilizam pelo parecer no momento em que cedem mercadorias para a divulgação em canais de mídias sociais por vídeo ou foto. A imagem e a publicidade se atrelam em um perfil de mídia social. O que antes era apenas o reconhecer para pertencer, mostra-se uma grande ilusão mercadológica na qual as pessoas atrelam o reconhecimento que alcançaram por demonstrarem o seu cotidiano a produtos e serviços que, muitas vezes, não possuem a eficiência proposta, mas que, pela proposta exercida pelo influenciador, são consumidos.

Retomando a questão do pertencimento sobre os meios de comunicação, o indivíduo encontra, na grande massa consumerista, a aprovação e o reconhecimento que ansiava, direcionando-se não mais à questão do ser, mas à do parecer, para ser aceito perante o grupo social e o poder que ele detém.

A sociedade de consumo tem como base de suas alegações a promessa de satisfazer os desejos humanos em um grau que nenhuma sociedade do passado pôde alcançar, ou mesmo sonhar, mas a promessa de satisfação só permanece sedutora enquanto o desejo continua insatisfeito; mais importante ainda, quando o cliente não está "plenamente satisfeito" - ou seja, enquanto não se acredita que os desejos que motivaram e colocaram em movimento a busca da satisfação e estimularam experimentos consumistas tenham sido verdadeira e totalmente realizados. ${ }^{14}$

A busca pela saciedade ao consumir o produto ofertado pelo influenciador, na maioria de ocasiões, não se completará, tendo em vista diversos fatores como tamanho do vestuário, condições de ambiente para a captura da imagem,

\footnotetext{
13 SANCHES-JUSTO, Joana. A primazia da imagem e a virtualização das relações na cultura das aparências. Revista Espaço Acadêmico, n. 153, 2014. p. 6. Disponível em: < http://periodicos.uem.br/ojs/index.php/EspacoAcademico/article/view/22859>. Acesso em: 02 jan. 2017.

${ }^{14}$ BAUMAN, Zygmunt. Vida para Consumo: a transformação das pessoas em mercadoria. Tradução Carlos Alberto Medeiros. Rio de Janeiro: Zahar, 2008. p. 63.
} 
composição de material do produto, dentre tantos outros. A plenitude de satisfação não será alcançada, porém o desejo de possuir o que o influenciador demonstrou como objeto de sua satisfação pessoal trará a saciedade do receptor-consumidor que, mesmo insatisfeito com o produto ou serviço, terá a satisfação do ter.

A questão da identidade virtual do digital influencer é composta pela necessidade de pertencimento a um determinado ambiente, nem que esse seja virtual, e a uma determinada comunidade, sua própria rede de amigos virtuais. Essa complexidade de fatores abrange também as necessidades do ser e da consideração do ser virtual, ou seja, a demonstração de um perfil aceito pelo grupo virtual formado, de modo que o perfil utópico criado na rede social jamais terá a sua concretização na vida cotidiana. Para Bauman "a 'identidade' só nos é revelada como algo a ser inventado, e não descoberto; como alvo de um esforço, 'um objetivo'; como uma coisa que ainda se precisa construir a partir do zero ou escolher entre alternativas e então lutar por ela e protegê-la lutando ainda mais"15.

Assim como na vida cotidiana, o influenciador digital necessita se reinventar a cada dia para manter a sua identidade virtual interessante ao seguidor. A relação de consumo é apenas uma das formas de exercer a influência nas mídias sociais, pois, além dela ainda há diversas maneiras de se manter a influência sobre os receptores da comunicação.

Outra forma influenciadora das mídias comumente utilizada é a exposição de opiniões sociais, políticas e religiosas sobre fatos diários. Tal exposição veiculada às opiniões pessoais sem cunho jornalístico é emitida todos os dias por influenciadores de jovens, adolescentes e adultos. Desenvolvem-se em ambiente virtual e em perfis particulares e, por vezes, não assumem nenhuma notoriedade perante a rede social, além da rede de amigos que ali estão inseridos.

Não obstante, na maioria dos casos, as opiniões ali transmitidas tomam proporções que fogem ao alcance do influenciador, principalmente quando se trata de fatos inverídicos ou de manifestações manipuladoras que, muitas vezes, possuem características de "redução, ocultação, fragmentação, inversão, exagero, manipulação, saturação ou invenção da verdade dos fatos" 16 .

Tais manifestações, na maioria dos casos, não encontram consequências ju-

${ }_{15}$ BAUMAN, Zygmunt. Identidade: entrevista a Benedetto Vecchi. Tradução Carlos Alberto Medeiros. Rio de Janeiro: Zahar, 2005. p. 21.

16 ANDRADE, Ronaldo Alves; MANSUR, Monica Tereza. Verdade, mentira e imprensa na sociedade da informação. PAESANI, Liliana Minardi (Org.). Direito da Sociedade da Informação III. São Paulo: Atlas, 2013. p. 104. 
rídicas relevantes. Porém, por serem emitidas por indivíduos que possuem tamanha relevância moral perante aqueles que os seguem, são reproduzidas, por seguidores, como se fossem a verdade dos fatos para as pessoas que compartilham de pensamentos semelhantes, gerando uma cadeia comunicativa complexa em discussões virtuais, por meio de comentários e fóruns.

Assim, os perfis individuais deixaram de ser apenas ambientes virtuais para a interação de grupos de amigos ou de pessoas que, em algum momento cotidiano, conheceram-se ou comunicaram-se. Passaram a ser uma imensa vitrina de opiniões e de mercadorias, como em um grande espetáculo em que a imagem e a aparência significam uma determinação de ações e pensamentos que devem ser expostos para que o indivíduo alcance o reconhecimento de uma identidade criada a partir da expectativa daqueles que o acompanham.

\section{CONSIDERAÇÕES FINAIS}

A questão aqui proposta vai além da responsabilidade do digital influencer sobre produtos, serviços e opiniões veiculados por meio da mídia social. O digital influencer não está elencado no rol dos anunciantes do Código do Consumidor, uma vez que ele não indica produtos para a compra de seus seguidores.

Muitos desses profissionais produzem vídeos de produtos recebidos como presentes e não como indicação. As fotos postadas são de produtos que eles utilizam como seus no dia a dia, a viagem e o hotel foram por ele desfrutados, o objeto central desta comunicação, em tese, não seria a divulgação do produto ou serviço, mas a divulgação do estilo de vida do influencer, do seu cotidiano.

Nesse caso, a divulgação é velada por um estilo luxuoso de vida. Inúmeras vezes, os influencers são contratados como modelos das marcas e, com isso, fazem a divulgação da imagem do produto em sua rede social podendo o seguidor acompanhar os seus passos de modo que ele anseie pelo mesmo produto, serviço e estilo de vida, ou seja, a forma como o marketing empresarial demonstra o produto não gera vínculo ao influencer.

Em outro sentido, aquele que exerce o poder da persuasão oral, por meio da expressão de suas opiniões e ideologias, muitas vezes o faz de forma difusa, não alcançando expressividade na identificação do indivíduo que está sendo criticado ou 
do dano que foi causado.

Tanto na expressão oral quanto na divulgação da imagem e da vida pessoal, o alcance da responsabilidade objetiva e subjetiva se torna nebuloso pela ausência de expressividade no sentido. Se o produto é visto com o influencer o desejo em consumir, do indivíduo, será maior. Se a ofensa foi difusa, não há meios de se identificarem os sujeitos ofendidos, ocorrendo a ausência de legitimidade para a busca do Direito.

Desse modo, o mercado encontrou uma forma eficiente de comunicar-se com seus consumidores sem que a publicidade possa ser considerada enganosa ou abusiva. Tem-se em vista que, no "anúncio", não há indicações, e a manifestação do pensamento tornou-se menos passiva de repressão por ausência de sujeitos ofendidos.

Assim, as improbabilidades comunicativas consideradas por Niklas Luhmann tornaram-se, perante as redes sociais e os digitais influencers, probabilidades em que a comunicação se opera com o contexto em que está inserida, com as memórias dos indivíduos, extensões temporais e espaciais (a foto será compartilhada em nível nacional e internacional) e, por fim, alcança o seu objetivo. A divulgação de um produto ou opinião por meio de uma rede globalizada, sem que para tal haja responsabilidade do "anunciante" ou emissor da mensagem.

\section{REFERÊNCIAS}

ANDRADE, Ronaldo Alves. MANSUR, Monica Tereza. Verdade, mentira e imprensa na sociedade da informação. PAESANI, Liliana Minardi (Org.). Direito da Sociedade da Informação III. São Paulo: Atlas, 2013. p. 104.

BAUMAN, Zygmunt. Vida para Consumo: a transformação das pessoas em mercadoria. Tradução Carlos Alberto Medeiros. Rio de Janeiro: Zahar, 2008, p. 63.

BAUMAN, Zygmunt. Identidade: entrevista a Benedetto Vecchi. Tradução Carlos Alberto Medeiros. Rio de Janeiro: Zahar, 2005. p. 21.

DEBORD, GUY. A sociedade do espetáculo. Trad. Terra à vista. Ilha do mel. eBookLibris. 2003. p. 13. Disponível em: < http://www.cisc.org.br/portal/biblioteca/ socespetaculo.pdf $>$. Acesso em: 12 jan. 2017. 
LUHMANN, Niklas. A improbabilidade da comunicação. Lisboa: Passagens, 2006. p. 47.

ROCHA, Leonel Severo; KING, Michael; SCHWARTZ, Germano. A verdade sobre a autopoiese no direito. Porto Alegre: Livraria do Advogado, 2009. p. 19.

SANCHES-JUSTO, Joana. A primazia da imagem e a virtualização das relações na cultura das aparências. Revista Espaço Acadêmico, no 153, 2014, p. 6. Disponível em: < http://periodicos.uem.br/ojs/index.php/EspacoAcademico/article/view/22859. Acesso em: 02 jan. 2017.

SOUSA, Mauro Wilton de. O pertencimento comum ao mediático. Significação Revistas de Cultura Audiovisual, v. 37, $\mathrm{n}^{0}$ 34, p. 31-52, 2010. Disponível em: http://www.revistas.usp.br/significacao/article/viewFile/68112/70670. Acesso em: 13 jan. 17.

Recebido em: $17 / 05 / 2017$

Aceito em: 28/09/2018 